Review Articles

\title{
Studies on the Mechanism of Insulin Action: Basic Concepts and Clinical Implications* **
}

\author{
K. D. Hepp \\ Forschergruppe Diabetes und III. Medizinische Klinik des Krankenhauses Schwabing, München, FRG
}

Key words: Insulin, receptor binding, diabetes, Sepharose-coupled insulin, PVP-coupled insulin, Chinese hamster, streptozotocin-diabetes, liver membranes, translation of hormone-receptor interaction, $3^{\prime}, 5^{\prime}$-AMP in fat cells, catecholamines, adenylate cyclase, phosphodiesterase, NSILA-S, 3',5'-GMP, calcium, local anaesthetics.

With the observation that pancreatectomy leads to the development of diabetes, Minkowski together with von Mehring paved the way to the discovery of insulin [1]. It was thus a straight road from the Strassburg of 1889 to the Toronto of 1921, and it seems appropriate to pay homage to the genius of Oskar Minkowski with a lecture on the mechanism of the action of insulin.

Two aspects of the complex problem of this insulin action have especially interested us over the last few years: the binding of the hormone to membranes with the possibility of a receptor defect in diabetes, and the quest for a primary effect upon enzyme systems in the plasma membrane of target cells.

\section{Receptor Binding and Receptor Defect}

The first stage in the mechanism of action of insulin is binding to specific sites in the plasma membrane. Many indirect studies indicate that these receptor sites are proteins or glycoproteins which are able to recognise and bind insulin [2]. Attempts at isolation

\footnotetext{
* Dedicated to Robert H. Williams

** Minkowski Award Lecture 1976
}

resulted in the solubilisation and partial purification of receptor proteins from plasma membrane preparations [2].

It is, however, still not entirely clear whether insulin elicits all of its acute effects from the outside of the cells. The effect of Sepharose-coupled insulin on fat-cells, i.e. insulin covalently linked to insoluble beads which are larger than fat-cells, seemed to prove this theory [3], but it soon became clear that the Sepharose-insulin particles "leak" insulin, i.e. give off free insulin which may be entirely responsible for the observed effect $[4,5]$. Another indication for an intracellular effect is the recent observation of binding to nuclei [6].

Evidence for an insulin receptor was presented as early as 1949 by Stadie [7], and Rieser, in his book on insulin action in 1967, wrote that "the combination of insulin with a receptor in a responsive cell is at the very heart of the problem of the hormone's action" [8]. Thus the hypothesis of a receptor for insulin in the plasma membrane seemed to have been accepted even before electronmicroscopic studies on the localisation, or experiments concerning the kinetics of binding were performed in more detail. In 1969 two important innovations have brought about the present flurry of binding studies, with a still ever increasing number of publications. One was the improvement of iodination of peptide hormones which fully maintained their biological activity, and the other the introduction of quantitative competition studies in order to demonstrate specificity $[9,10]$. For insulin binding to membranes specific binding was defined as that portion of labelled hormone which could be displaced by a maximal concentration of unlabelled insulin [11], but the significance of the remaining non-specific binding, which can sometimes be quite high, is not clear. Kinetic studies on binding of labelled hor- 


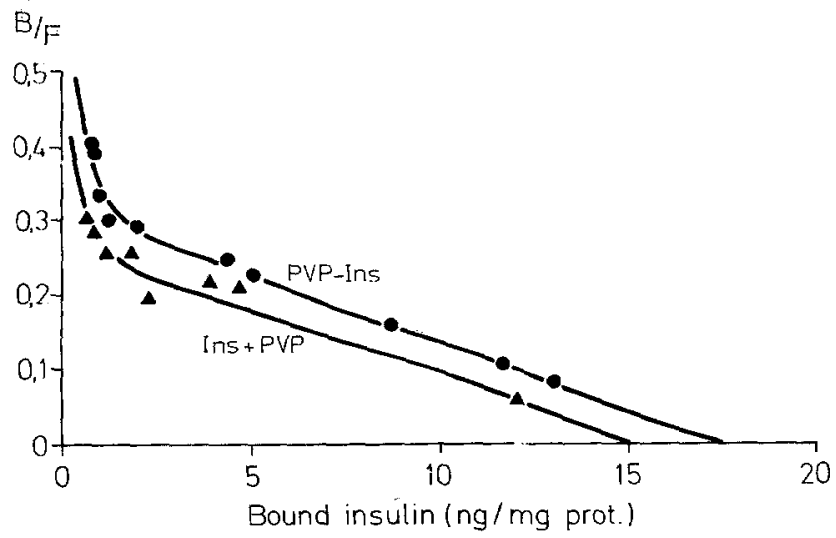

Fig. 1. Binding of insulin coupled to polyvinyl-pyrollidone in comparison to native insulin. Scatchard plot of binding of $\left[{ }^{125} \mathrm{I}\right]-$ insulin to plasma membranes from rat liver in presence of increasing concentrations of PVP-insulin and insulin plus PVP. Curvilinear plot suggests negative cooperativity; dimerization of insulin can be excluded in the case of PVP-coupled hormone. (mol. wt. of PVP-insulin 40-60000). (K. D. Hepp and H. J. Kolb, unpublished results)

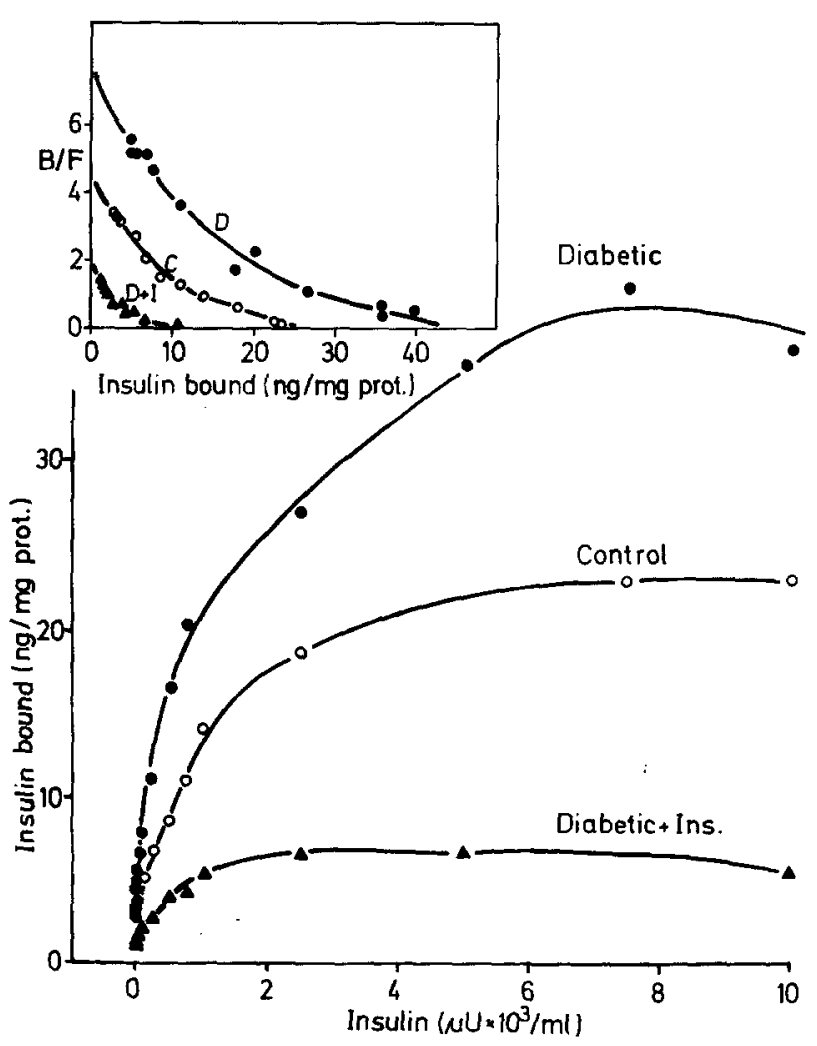

Fig. 2. Insulin binding to liver plasma membranes from control, diabetic and insulin-treated diabetic Chinese hamsters. Plasma membranes were prepared from the livers of eight animals in each group. Insulin treatment for 7 days prior to the experiment. The experiment shows binding at equilibrium $\left(25^{\circ}\right)$ with various insulin concentrations. "Non-specific binding" i. e. labelled hormone not displaced by $1 \mathrm{U} / \mathrm{ml}$, has been subtracted. Insert shows Scatchard plot of same data suggesting no general difference in affinity but in receptor capacity (number of binding sites, see also [20]) mone are now the main approach to the mechanism of hormone-receptor interaction, and one should not forget that the molecular events are still poorly understood. Insulin binding displays characteristics of negative cooperativity, i.e. an increasing number of hormone-receptor complexes reduces the binding affinity of the remaining free receptors [12]. The main sign for this is a non-linear Scatchard-plot, but it is understood that interpretations other than negative cooperativity are possible [13]. We could recently exclude self-aggregation as a possible cause of non-linear Scatchard-plots by the use of insulin coupled to polyvinyl-pyrollidone, which does not dimerize, but which also displays non-linearity (Fig. 1).

Of great clinical importance was the finding of Kahn et al. [14] who observed a considerable decrease in total binding of insulin to the target tissues of obese-hyperglycaemic mice. These studies were extended to strains with other types of genetichyperglycaemic syndromes such as the New Zealand Obese Mouse [15] and the KK-mouse [16] and implied that hyperinsulinism and insulin resistance is correlated with a decrease in insulin receptors. Furthermore, studies in diabetics and insulin-resistant obese patients showed also that their tissues exhibit reduced insulin binding $[17,18]$. This meant that the basic, and possibly genetic, defect in insulin resistant patients consists of a reduction in the number of insulin receptors.

We became interested in the reverse situation, i. e. lack of insulin due to B-cell insufficiency, such as in the genetic diabetes of Chinese hamsters. These animals are in many ways similar to the juvenile-type diabetic [19]. Here the situation is exactly the opposite of that of the obese-hyperinsulinaemic syndrome: The binding capacity of liver membranes is increased, i.e. the animal tries to compensate for the lack of insulin with an increase in the number of receptors [20]. Insulin treatment, on the other hand, reduces the number of receptors towards and even below the normal condition (Fig. 2). The same phenomenon can be shown in experimental diabetes after streptozotocin treatment: again the binding capacity of the plasma membranes was strongly enhanced in the diabetic animals, and reduced below that of the control group after insulin therapy [21]. This implies relatively rapid adaptive changes of the receptor population in an inverse relation to the mean insulin concentration, which is also reflected by the increase in receptor number when obese-hyperinsulinaemic patients [17] or animals [22] are starved (Table 1). Thus the hormone, in some still unknown way, controls the turnover or perhaps just the availability of its binding site in the 
plasma membrane. Such an adaptive phenomenon would argue against a receptor defect as a primary genetic lesion in diabetes, which is rather disappointing considering that binding studies had raised such high hopes. With respect to the role of insulin receptors in the pathogenesis of the diabetic syndrome, there remains the possibility that humoral factors may impair binding, as shown in the interesting study by Flier et al. on patients with diabetes and acanthosis nigricans [23]. In fact these patients, although lean, exhibited the characteristics of insulin resistance, and the substance which was found to impair binding turned out to be an autoantibody, directed against the patient's own hormone receptors.

\section{Translation of Hormone-Receptor Interaction}

One of the most interesting problems in insulin action, and perhaps, molecular endocrinology in general, is the translation of hormone-receptor interaction into a biological effect. Binding of insulin to its receptors may first result in changes in the reactivity of membrane proteins such as enzyme and carrier systems, and then lead to the formation of a second messenger in a manner similar to our concept of the mechanism of action of catabolic hormones. Undoubtedly in muscle and to some extent in adipose tissue, the activation of facilitated transport of glucose is of major physiological importance. However, equally important mechanism in the pathogenesis of diabetes, such as the control of glycogenolysis and gluconeogenesis in the liver and the regulation of lipolysis in adipose tissue, are influenced by insulin independently of its effect on glucose transport (Table 2). In fact insulin is so far the only anabolic hormone that acutely prevents the catabolic effect of a number of hormones, such as glucagon in the liver and adrenaline in adipose tissue. Metabolic control can thus be viewed as a fine balance between insulin on the one hand and catabolic hormones on the other. Due to the monumental discovery of Sutherland and his associates it became clear that cAMP is the key substance in the regulation of catabolic processes in tissues that are the main targets of insulin action. A major breakthrough therefore, seemed to be the discovery of Butcher and coworkers that insulin can lower the elevated levels of cAMP in adipose cells in the presence of catabolic hormones [24]. Such an effect was also demonstrated in the isolated perfused liver [25]. The concept that cAMP can also function as a second messenger for insulin was subsequently challenged, mainly on the grounds that there is a poor correlation between the metabolic indices such as, for instance, lipolysis in
Table 1. Regulation of insulin receptor capacity under conditions associated with hyperinsulinism and insulin deficiency. The observations suggest an inverse relationship between hormone level and receptor number

\begin{tabular}{|c|c|}
\hline $\begin{array}{l}\text { Obesity } \\
\text { Corticosteroid treatment } \\
\text { Insulinoma } \\
\text { Certain types of diabetes }\end{array}$ & $\begin{array}{l}\text { Insulin levels } \uparrow \\
\text { Binding capacity } \downarrow\end{array}$ \\
\hline $\begin{array}{l}\text { Streptozotocin } \\
\text { Chinese hamsters } \\
\text { Hypophysectomy } \\
\text { Juvenile diabetes }\end{array}$ & $\begin{array}{l}\text { Insulin levels } \downarrow \\
\text { Binding capacity } \uparrow\end{array}$ \\
\hline
\end{tabular}

Table 2. Antagonism between insulin and catabolic hormones in the regulation of anabolic and catabolic pathways (gluconeogenesis, in a strict sense, is not a catabolic process; it is, however, enhanced under catabolic conditions)

\begin{tabular}{ll}
\hline Insulin & Anabolic processes \\
Enhances & $\begin{array}{l}\text { Protein synthesis } \\
\text { Lipid synthesis }\end{array}$ \\
Glycogen synthesis & Catabolic processes \\
Inhibits & $\begin{array}{l}\text { Proteolysis } \\
\text { Gipolysis-ketogenesis }\end{array}$ \\
\hline & Glycogenolysis
\end{tabular}

adipose tissue and the observed lowering of cAMP $[26,27]$. In the course of the debate, other messengers were introduced, such as $\mathrm{Ca}^{++}$(based on Rasmussen's concept of an equally universal metabolic role of this ion as CAMP [28]), and more recently by Illiano and coworkers, cGMP [29]. Let us first turn to the possibility of a central role of cAMP in insulin action.

\section{The Effect of Insulin on the Levels of $3^{\prime}, 5^{\prime}$-AMP in Fat Cells}

In view of the doubts that were raised with respect to the essential role of cAMP in the antilipolytic effect of insulin, we found it worthwhile to conduct studies on the effect of insulin on cAMP levels in fat-cells. The aim was to answer two questions: (1) what are the early kinetics of the effect of insulin and (2) can one gain information as to the underlying enzymatic mechanism?

After addition of isoproterenol to isolated fat cells a rapid rise of cyclic AMP is observed, which within two minutes is followed by a steady state, at which time the velocity of the adenylate cyclase system should be equal to that of the phosphodiesterase (Fig. 3). In the presence of the phosphodiester- 
A

Effect of Isoproterenol

$\left(10^{-6} \mathrm{M}\right) \bullet$

Basal o-o

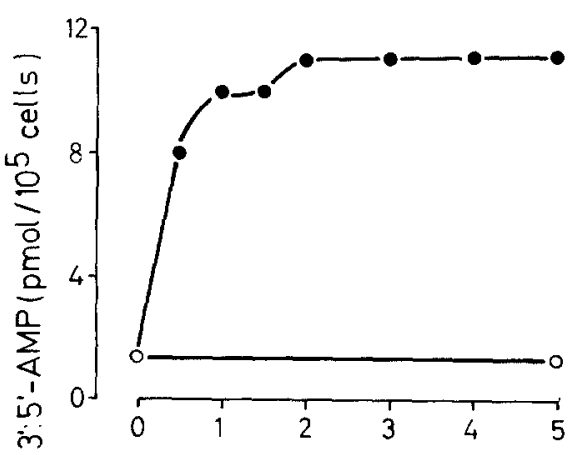

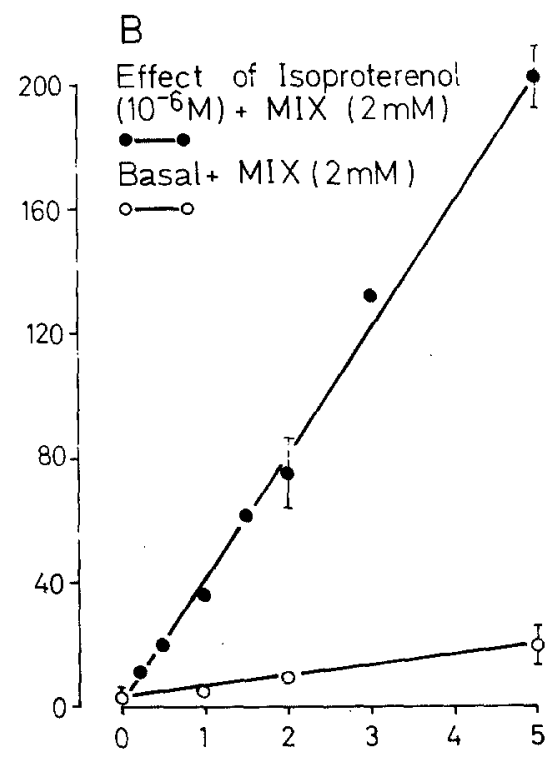

Incubation time (min)

Fig. 3. Kinetics of cAMP in isolated fat cells after addition of isoproterenol. Comparison of the effect in absence (A) and presence (B) of the phosphodiesterase-blocker methyl-isobutyl xanthine (MIX). From Häring et al. [33]
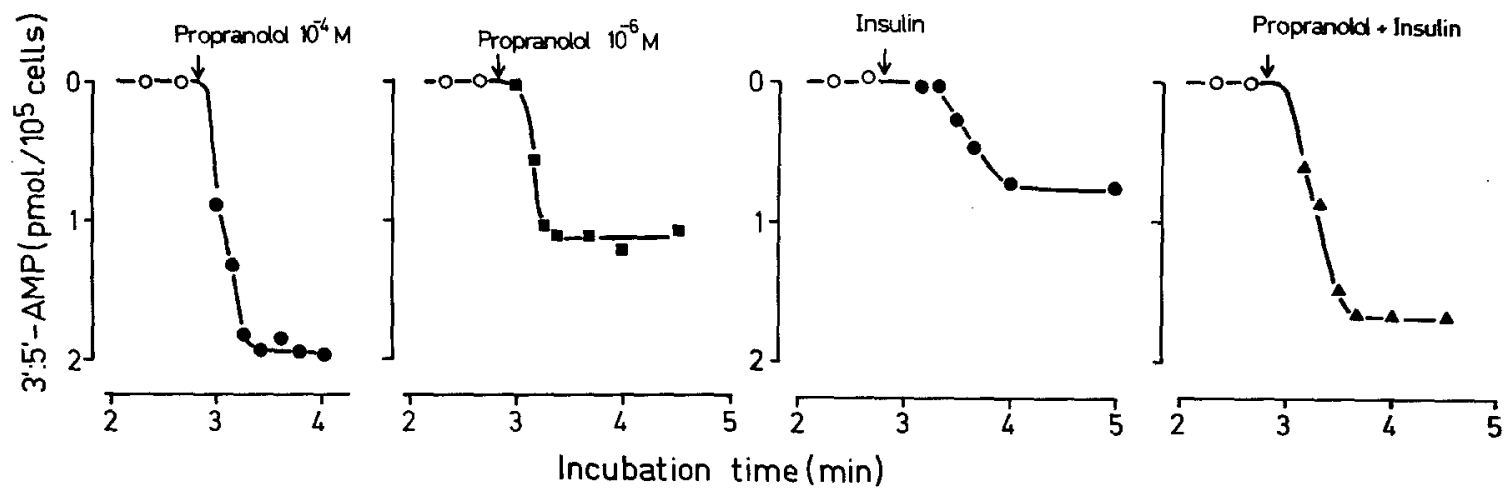

Fig. 4. Net effects of propranolol and insulin $(100 \mu \mathrm{U} / \mathrm{ml})$ when added at plateau phase, 3 min after isoproterenol (10 $\left.{ }^{-6} \mathrm{M}\right)$. No additional effect was observed when insulin was added together with the maximal dose of propranolol. (Data from Häring et al. [33])

ase inhibitor methyl-isobutyl-xanthine (MIX) not only a doubling of the initial rate of cyclic AMP formation was seen, but also a linear increase throughout the first five minutes. Provided that MIX acts exclusively on the phosphodiesterase, one can postulate an immediate activation of this enzymc (Fig. $3 \mathrm{~A}$ ), resulting in the first steady state. In fact, activation of phosphodiesterase activity in the fat cell has been shown after addition of lipolytic hormones to the intact cell, cAMP itself being the activator [30]. The linear rate in the presence of MIX argues against the influence of a feedback inhibitor at this stage, although MIX could still prevent the formation of such an inhibitor under these conditions. The tendency to attain an early equilibrium is also seen after the addition of propranolol, where it is evident that the level of the new steady state and not the rate of fall of the cyclic nucleotide depends on the concentration of the blocker (Fig, 4). The $\beta$-blocker prevents the hormonal activation of the adenylate cyclase system in a dose-dependent fashion [31] and the rate of cAMP formation should determine the level of the equilibrium. As yet the mechanism is not clear by which the phosphodiesterase system is involved in maintaining the steady state: activation of 'low- $\mathrm{K}_{\mathrm{M}}$ phosphodiesterase' by hormones and cAMP (Table 3) $[30,32]$ or simply the activity of the 'high- $K_{M}$ enzyme' at substrate concentrations within the range of near zero-order kinetics.

The addition of insulin together with isoproterenol at the start of incubation leads to a significant effect after one minute (Fig. 5). Insulin can- 
Table 3. Stimulation of low $-K_{M}$ phosphodiesterase activity in homogenate after previous incubation of intact fat cells with various hormones and chemicals

\begin{tabular}{ll}
\hline No $\mathrm{Ca}^{++}$required: & $\mathrm{Ca}^{++}$essential: \\
DB - cAMP & Insulin \\
Theophylline & ACTH \\
Catecholamines & \\
Glucagon & \\
\hline
\end{tabular}

not entirely prevent the initial rise in the cyclic nucleotide and, like propranolol, leads to the formation of a new steady state. The same amount of insulin has no effect upon the basal levels of cyclic AMP. Later addition of insulin to the stimulated system leads to a rapid fall after 30 seconds, and a new equilibrium is attained after 90 seconds. Insulin acts somewhat less rapidly than propranolol but the combination of insulin with a submaximal dose of propranolol is additive, whereas the effect of a maximal concentration of propranolol is not further enhanced by insulin. These experiments suggest that insulin acts in a similar way to propranolol, i.e. via inhibition of the catecholamine-stimulated adenylate cyclase.

An effect of insulin in the presence of a phosphodiesterase inhibitor would also be indicative of a primary effect at the cyclase level. Butcher et al. have already shown a clear effect in the presence of methyl xanthines upon the catecholamine-stimulated system in the fat cell [24]. However, if one compares cAMP levels after 5 min of incubation under various concentrations of MIX with that found in the presence of isoproterenol and insulin, a dosedependent decrease in the effect of insulin is observed which at first hand would suggest an effect of insulin upon phosphodiesterase activity, with a smaller effect of insulin remaining at maximal concentrations of MIX [33]. Our interpretation of this observation was that insulin can affect both formation and breakdown of cAMP [33]. Yet from such indirect experiments involving measurement of cAMP concentration in tissues it is impossible to be sure how the hormone prevents the effect of catabolic hormones; whether it antagonizes the effect of catabolic hormones upon the adenylate-cyclase system or whether it stimulates phosphodiesterase activity while the cyclase system remains activated by catabolic hormones.

In the course of experiments on the control of adenylate cyclase activity in particulate preparations from mouse liver we observed an antagonism of insulin added in vitro to the stimulatory action of glucagon [34]. This was the first observation of a direct effect of physiological concentrations of insulin on a broken cell system. In support of these findings NSILA-S preparations from the laboratories of Froesch and Humbel, showed a similar effect on adenylate cyclase activity, whereas NSILA-S, rendered biologically inactive by reduction and aminoethylation, had no effect [35]. In these experiments we could also demonstrate evidence for binding of NSILA-S to our membrane preparation, which underlined the hormonal character of this material [35]. When the system was stimulated with $10 \mathrm{mmol} / 1 \mathrm{NaF}$, which is thought to stimulate the adenylate cyclase at a site which is more proximal to the catalytic unit (Fig. 6), no effect of insulin or NSILA was observed [34, 35]. This suggested that insulin and NSILA interfere with the translation or coupling process in the mechanism of action of catabolic hormones between receptor and catalytic unit of the adenylate cyclase system. Further studies on adenylate cyclase in liver preparations from streptozotocin-diabetic mice revealed an increased sensitivity towards glucagon without change in the fluoride-stimulated activity. This indicated that, with insulin deficiency, the translation of the glucagon signal from receptor to the catalytic unit is augmented [35]. These findings corresponded with the observed increase in cAMP levels in the diabetic liver [36].

In view of these observations it seemed obvious to test the action of insulin upon the adenylate cyclase system in fat cell membranes, using fat cell "ghosts", a preparation which had been developed and thoroughly studied in Rodbell's laboratory [37, 38]. Again insulin was found to inhibit the effect of submaximal concentrations of norepinephrine, ACTH and glucagon $[39,40]$ (Fig. 7). In analogy to what has been observed with mouse liver membranes, the effect of fluoride was not antagonized; insulin alone had no effect. As in the case of insulin effects on lipolysis and cAMP levels in intact cells, high insulin concentrations showed a paradoxical reversal, which suggested that the adenylate-cyclase reaction may in fact be a controlling step in the regulation of antilipolysis (Fig. 8). The effect of insulin disappeared after trypsin treatment of intact cells prior to preparation of "ghosts", but could be regenerated by further incubation in absence of trypsin [40] in analogy to what has been observed by Kono [41]. Again partially purified NSILA-S exerted an inhibitory action upon the catecholaminestimulated system, but its effect was not abolished by trypsin treatment [40]. In a study with plasma membrane preparations from fat cells, the inhibition of norepinephrine-stimulated adenylate cyclase activity was characterized by an effect on $V_{\max }$ without change in affinity towards ATP or $\mathrm{Mg}^{++}[42]$. 


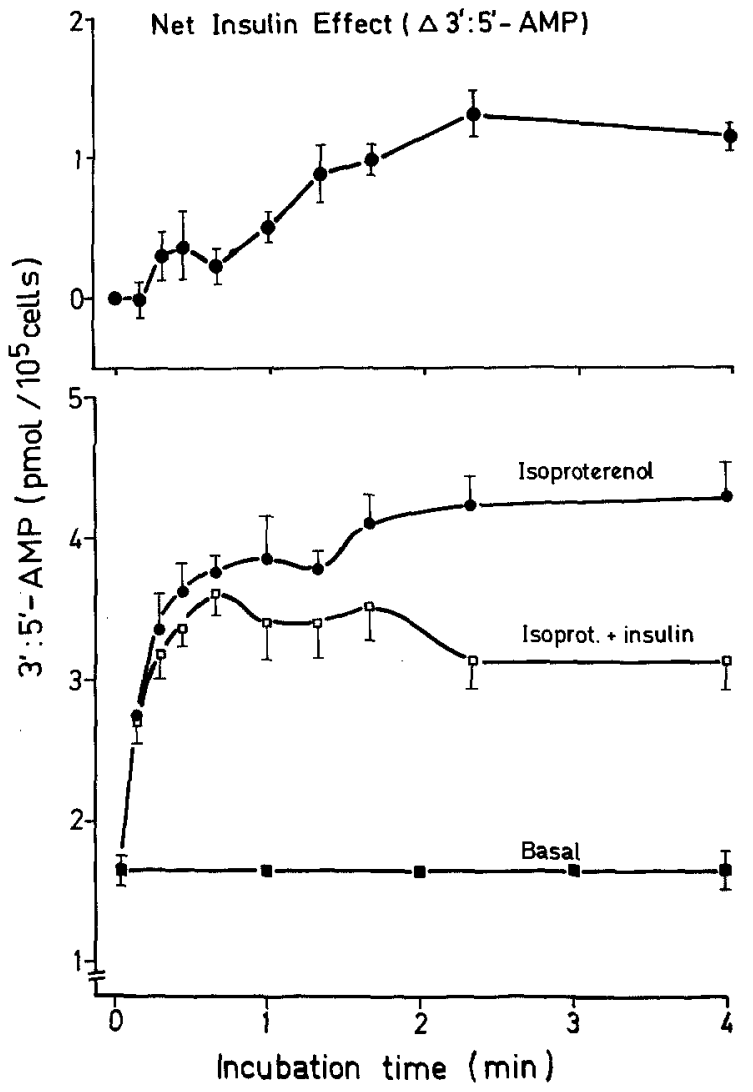

Fig. 5. Effect of insulin $(100 \mu \mathrm{U} / \mathrm{ml})$ on cAMP concentration in isolated fat cells in the presence of isoproterenol $\left(10^{-6} \mathrm{M}\right)$. Both hormones were added at the start of incubation. At one min, a significant effect of insulin can be demonstrated $(p<0.01$, paired comparison; the fig. shows mean of 8 experiments \pm S.E.M.). No effect of insulin was seen on basal system. (Data from Häring et al. [33])

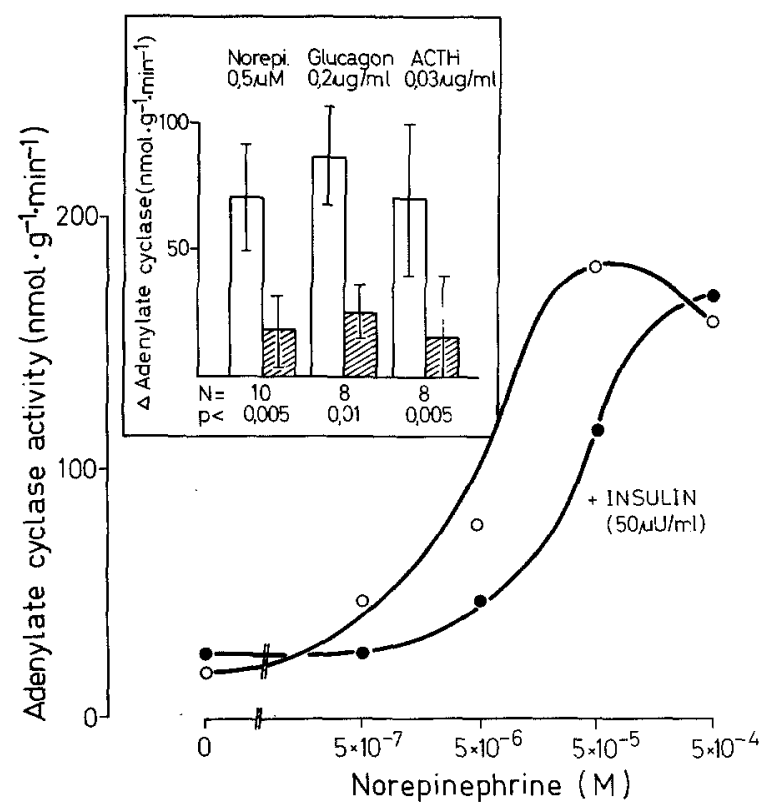

Fig. 7. Modulation of the effect of lipolytic hormones on adenylate cyclase activity in fat cell "ghosts" by insulin. Insert shows effect of $50 \mu \mathrm{U} / \mathrm{ml}$ of insulin in the presence of submaximal concentrations of norepinephrine, glucagon, and ACTH. (Data from Renner et al. [40])

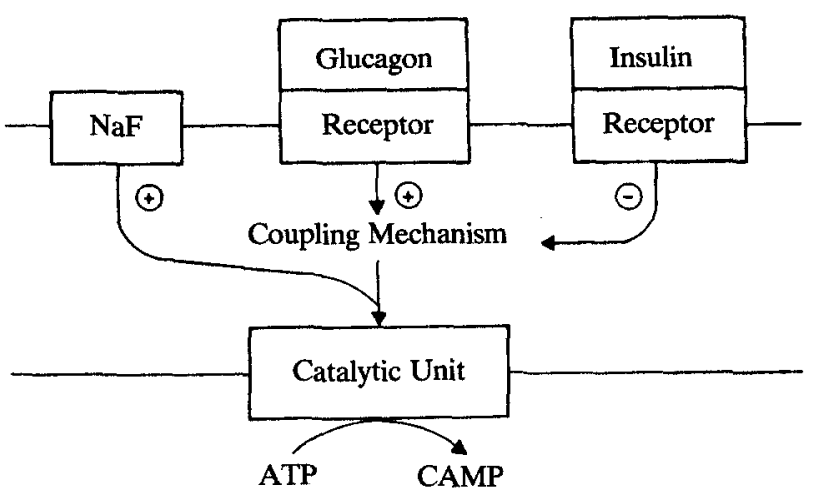

Fig. 6. Model of insulin action upon glucagon-stimulated adenylate cyclase in liver plasma membrane. Insulin prevents activation of catalytic unit by glucagon by interfering with coupling mechanism; it has no effect when the system is stimulated by sodium fluoride which is thought to activate directly the catalytic unit

Using different crude membrane fractions from liver and adipose cells, Illiano and Cuatrecasas observed essentially the same effects [43]. In other studies on fibroblast cultures [44], the islets of Langerhans [45] and Neurospora Crassa [46], direct effects of low insulin concentrations upon the adenylate cyclase system were shown, again in antagonism to the action of catabolic hormones. In contrast to these investigations, a number of workers reported negative observations with respect to insulin action on the adenylate cyclase system [47-50]. With purified plasma membrane preparations we found it difficult consistently to reproduce the effect of insulin and it appears that only fresh material is insulin sensitive, whereas manipulation of membranes during purification steps results in a loss of the effect [51].

In the course of studies on phosphodiesterase activity in fat cells Loten and Sneyd provided evidence for two enzyme systems with different Michaelis constants [52]. As suggested before [53] they found an effect of insulin upon the 'low $\mathrm{K}_{\mathrm{M}}$ enzyme' [52]. It is important to note that this effect was observed in the homogenate after previous incubation of the intact cell with the hormone, and that direct addition to broken cell preparations has not resulted in clear effects. This observation was confirmed in several laboratories [30, 32] and by ourselves [40] and was found to be most pronounced in fractions corresponding to plasma membranes $[30,54]$. However, it soon became apparent that insulin antagonists, such as catecholamines and glucagon, also stimulated the low $\mathrm{K}_{\mathrm{M}}$-phosphodiesterase $[30,32]$, an enzyme which is probably activated by cAMP [30]. It would be difficult to reconcile this finding with the observed antagonism of insulin and catabolic hormones. More recently, Desai and Hollenberg added another argument against the concept 
of a direct action on the phosphodiesterase by showing that the activation of the low- $\mathrm{K}_{\mathrm{M}}$ enzyme by insulin requires $\mathrm{Ca}^{++}$-ions during the preincubation step [55]. In the presence of EGTA no effect upon the phosphodiesterase is observed, whereas under the same conditions, cAMP levels fall and lipolysis is inhibited [55, 56] (see also Table 3).

A similar dependence on the presence of $\mathrm{Ca}^{++}$ was recently reported by Fain and Butcher [57] who were able to confirm the finding of Illiano and coworkers of a rapid rise of the levels of $3^{\prime}, 5^{\prime}$-GMP in isolated fat cells after the addition of insulin [29]. However, addition of catabolic hormones and ionophores led to a similar increase, whereas no effect was seen in the absence of $\mathrm{Ca}^{++}$[57]. Apart from the fact that the metabolic actions of cyclic GMP are largely unknown, the data speak against an essential role of cGMP as a messenger of insulin, at least in the regulation of lipolysis.

Careful experiments by Clausen and coworkers have shown an effect of insulin on calcium transport in muscle and adipose tissue [58]. Furthermore, agents which promote a rise in intracellular calcium, such as local anaesthetics, were found to mimic the antilipolytic effect of insulin [59]. A number of key enzymes which are under regulation of insulin were also found to be sensitive to calcium, among these the protein kinase and the triglyceride lipase systems [60], pyruvate dehydrogenase [61] and glycogen synthetase [62]. Kissebah et al. have therefore recently proposed a key role of $\mathrm{Ca}^{++}$in the mechanism of insulin action. The central mechanism would be a rise in cytosolic $\mathrm{Ca}^{++}$promoted under the influence of insulin [63]. An important argument in favour of this theory was provided by the effect of local anaesthetics which promote $\mathrm{Ca}^{++}$uptake and inhibit lipolysis without lowering, but rather increasing, the levels of cAMP [59]. This suggested that changes in cAMP are not essential in the control of lipolysis and that calcium is the messenger which antagonises the activation of the lipase and other key enzymes. However, we have recently found that local anaesthetics, like insulin, can inhibit the effect of catecholamines on fat cell adenylate cyclase without changing the basal or the fluoride-stimulated activity (Fig. 9). Thus, like insulin, local anaesthetics interfere with the translation of the hormone signal between receptor and the catalytic unit of the adenylate cyclase [64]. Local anaesthetics could therefore antagonize the action of catecholamines at the adenylate cyclase step without decreasing, but even elevating, the overall cellular concentration of cAMP. One could speculate from this that (1) the total cAMP content does not necessarily reflect changes in a small but metabolically active compart-
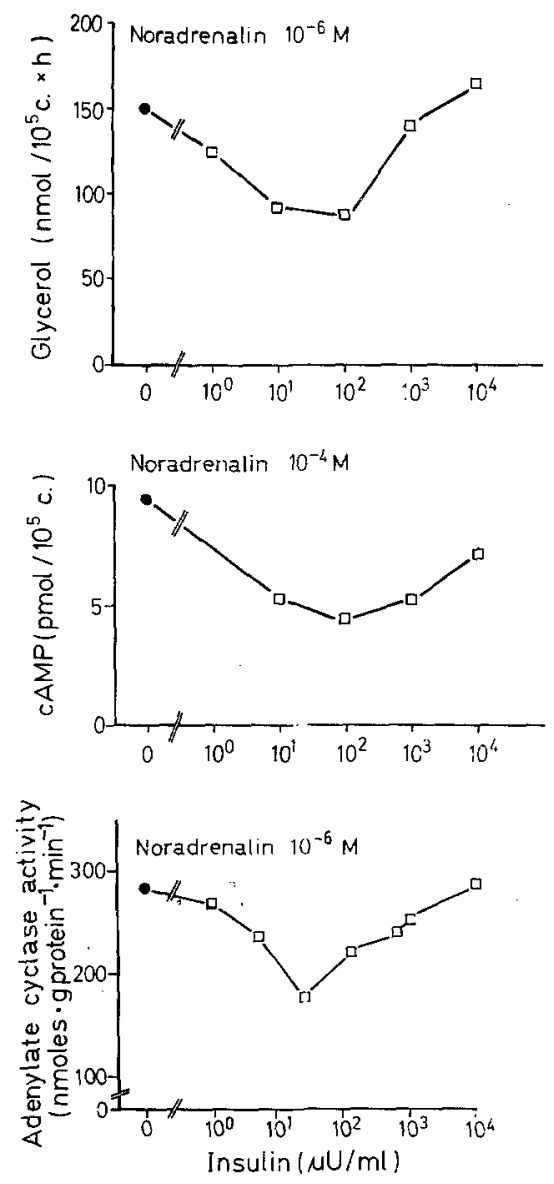

Fig. 8. Comparison of the effect of insulin on lipolysis, cAMP levels, and adenylate cyclase activity in fat cells. Similarity and paradoxical reversal of dose-response curves is found for all three indices

ment, and (2) that changes in adenylate cyclase activity in the plasma membrane may precede hormone effects on $\mathrm{Ca}^{++}$distribution.

On the basis of the data provided by this and several other laboratories, the adenylate cyclase system can be viewed as one of the primary targets of insulin's action. This implies cyclic AMP as a second messenger; whether the universal one, remains uncertain.

So far there is little evidence of an essential role of cAMP in the effect of insulin on facilitated transport, and it is not clear to what extent it is involved in the active transport of ions across the plasma membrane. Therefore, despite an unusual wealth of information, is is still exceptionally difficult to arrive at a conclusive, let alone a unitary, concept of the mechanism of the action of insulin (Fig. 10).

In this lecture the emphasis was on the role of insulin as a modulator of the effect of catabolic hormones; fine regulation in the organism invariably consists of an interplay of agonists and antagonists. 

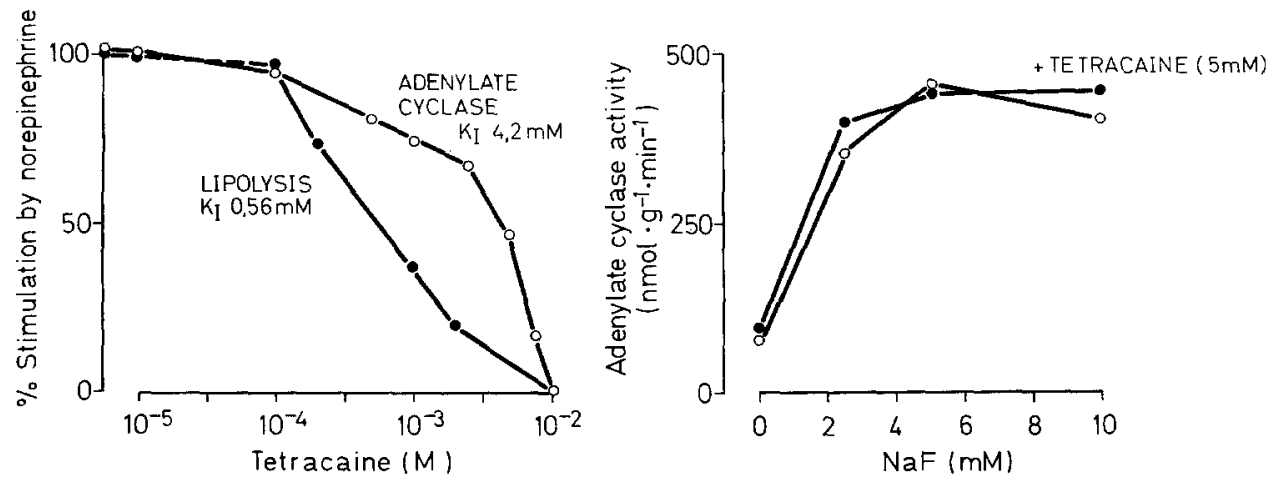

Fig. 9. Effect of local anaesthetic on lipolysis and adenylate cyclase activity. Lipolysis was stimulated by $10^{-6} \mathrm{M}$ norepinephrine in intact cells, adenylate cyclase was measured in fat cell "ghosts" in the presence of $10^{-6} \mathrm{M}$ norepinephrine. No effect of $5 \mathrm{mM}$ tetracaine was observed in the presence of $\mathrm{NaF}$ (right), suggesting an effect upon the coupling process between receptor and catalytic unit as proposed for insulin (Fig. 6)

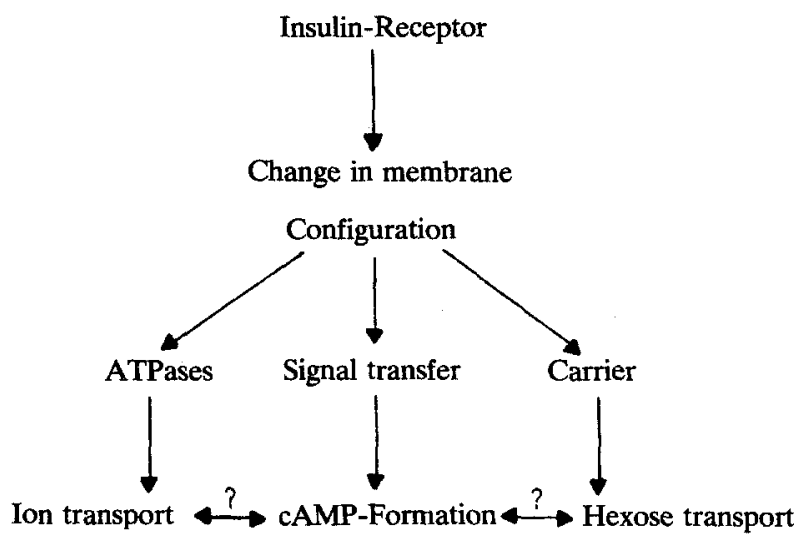

Fig. 10. Insulin action at the plasma membrane level. Binding of the hormone to its receptor may result in structural changes with subsequent activation of transport processes (ATPases and carrier systems) as well as modulation of signal transfer from receptor to catalytic unit of the cyclase system. The model indicates the possibility of an effect of cAMP on transport mechanisms. The model applies to the fat cell; some of the mechanisms are not operative in other tissues, such as liver (stimulation of hexose transport) and muscle (effect on cyclase system)

We know from clinical studies how important the anti-catabolic, transport-unrelated effects of insulin are, for instance in the case of ketogenesis or glucose homolostasis, where the effect on the liver seems to be of greater importance than that on glucose transport in peripheral organs. At present it does not seem to be necessary to postulate a new messenger in addition to the ones already discussed. Of these, it appears that the increase in cGMP depends on the presence of calcium, but that insulin effects on cells can be easily demonstrated in the absence of calcium. Thus effects on transmembrane calcium transport are not a prerequisite for the metabolic response.
Acknowledgements. I wish to acknowledge the excellent work of my colleagues and friends who greatly contributed to this lecture with their experiments and ideas. It was my privilege to act here as spokesman for our group. This includes especially Drs. Rolf Renner, with whom I have been in close cooperation for several years, Wolfgang Kemmler, and Hansjoachim von Funcke, splendid investigators and clinicians, and Ms. R. Anding-Edel, Ms. J. Langley and Ms. E. Rattenhuber who provided skilful and competent technical assistance. Some of the more recent findings were part of the excellent doctoral thesis of $\mathrm{H}$. U. Häring.

I am most grateful to Professor O. H. Wieland who has been my teacher and mentor in biochemical research for many years, and Professor $\mathrm{H}$. Mehnert, my clinical teacher and friend, for their continued encouragement and support. They succeed in maintaining a unit in which creative basic research, clinical investigation and patient care is satisfactorily combined, a situation which unfortunately, is still rare on this side of the Atlantic.

My warmest thanks are also due to Drs. W. Guder, H. Kolb, E. Siess, and L. Weiß for their collaboration and helpful criticism throughout many years.

Like many European researchers of my generation, I owe much to American Medicine and Science and the eminent scientists, clinicians and teachers I had the privilege to meet and work with in the U.S. To one of them, Dr. Robert H. Williams, Professor of Medicine at the University of Washington, Seattle, I dedicate this paper.

The research work reported herein was largely supported by grants from the Deutsche Forschungsgemeinschaft, Bad Godesberg. The author was recipient of the 1972 Friedrich-Bertram Award of the German Diabetes Association and a Pfizer-Europe Travel Grant in 1974.

\section{References}

1. Minkowski, O.: Die Lehre vom Pankreas-Diabetes in ihrer geschichtlichen Entwicklung. Münch. Med. Wochenschr. 76, 311-315 (1929)

2. Cuatrecasas, P.: Membrane receptors. Annu. Rev. Biochem. 43, 169-214 (1974)

3. Cuatrecasas, P.: Interaction of insulin with the cell membrane: The primary action of insulin. Proc. Natl. Acad. Sci. USA 63, 450-457 (1969)

4. Kolb, H. J., Renner, R., Hepp, K.D., Weiss, L., Wieland, O.H.: Re-evaluation of sepharose-insulin as a tool for the 
study of insulin action. Proc. Natl. Acad. Sci. USA 72, 248-252 (1975)

5. Davidson, M. B., Van Herle, A. J., Gerschenson, I.. E.: Insulin and sepharose-insulin effects on tyrosine transaminase levels in cultured tat liver cells. Endocrinology 92, 1442-1446 (1973)

6. Goldfine, I.D., Smith, G.J.: Binding of insulin to isolated nuclei. Proc. Natl. Acad. Sci. USA 73, 1427-1431 (1976)

7. Stadie, W.C., Hargaard, N., Hills, A. G., Marsh, J.B.: The chemical combination of insulin with muscle (diaphragm) of normal rat. Am. J. Med. Sci. 218, 265-274 (1949)

8. Rieser, P.: Insulin, membranes, and metabolism. Baltimore: The Williams and Wilkins Co. 1967

9. Lefkowitz, R. J., Roth, J., Pricer, W.: ACTH receptors in the adrenal: specific binding of ACTH- ${ }^{125} \mathrm{I}$ and its relations to adenyl cyclase. Proc. Natl. Acad. Sci. USA 65, 745-752 (1970)

10. Goodfriend, T., Lin, S.-Y.: Angiotensin receptors. Clin. Res. 17, 243 (1969)

11. Freychet, P., Kahn, R., Roth, J., Neville, D. M.: Insulin interaction with liver plasma membranes. Independence of binding of the hormone and its degradation. J. Biol. Chem. 247, 3953-3961 (1972)

12. De Mcyts, P.: Cooperative properties of hormone receptors in cell membranes. J. Supramol. Struct. 4, 241-258 (1976)

13. Taylor, S. I.: Binding of hormones to receptors. An alternative explanation of nonlinear Scatchard plots. Biochemistry 14, 2357-2361 (1975)

14. Kahn, C. R., Neville, D.M., Roth, J.: Insulin-receptor interaction in the obese-hyperglycemic mouse. J. Biol. Chem. 248, 244-250 (1973)

15. Baxter, D., Lazarus, N. R.: The control of insulin receptors in the New Zealand Obese Mouse. Diabetologia 11, 261-267 (1975)

16. Kern, P., Picard, J., Caron, M., Veissière, D.: Decreased binding of insulin to liver plasma membrane receptors in hereditary diabetic mice. Biochim. Biophys. Acta 389, 281-289 (1975)

17. Archer, J. A., Gorden, P., Roth, J.: Defect in insulin binding to receptors in obese man. Amelioration with caloric restriction. J. Clin. Invest. 55, 166-174 (1975)

18. Olefsky, J.M., Reaven, G.M.: Decreased insulin binding to lymphocytes from diabetic subjects. J. Clin. Invest. 54, 1323-1328 (1974)

19. Gerritsen, G. C., Dulin, W. E.: Characterization of diabetes in the Chinese hamster. Diabetologia 3, 74-84 (1967)

20. Hepp, K.D., Langley, J., von Funcke, H.J., Renner, R., Kemmler, W.: Increased insulin binding capacity of liver membranes from diabctic Chinese hamsters. Nature 258, 154 (1975)

21. Kemmler, W., Renner, R., von Funcke, H. J., Hepp, K. D.: Increased capacity of insulin receptors in plasma membranes from insulin deficient rodents: reversal by insulin therapy (Abstr.). IX. Congress of the Int. Diabetes Fed., p. 160. Amsterdam: Excerpta Medica Congress Series 1976

22. Kahn, C.R., Neville, D.M., Soll, A., Roth, J.: Deficiency of insulin receptors in the insulin resistant obese hyperglycemic mouse ( $\Lambda$ bstr.). VIII. Congr. Int. Diabetes Fed., p. 75. Amsterdam: Excerpta Medica Congress Series 1973

23. Flier, J:S., Kahn, C. R., Roth, J., Bar, R. S.: Antibodies that impair insulin receptor binding in an unusual diabetic syndrome with scverc insulin resistance. Science 190, 63-65 (1975)

24. Butcher, R.W., Baird, C.E., Sutherland, E.W.: Effect of lipolytic and antilipolytic substances on adenosine $3^{\prime}, 5^{\prime}$-monophosphate levels in isolated fat cells. J. Biol. Chem. 243, 1705-1712 (1968)
25. Exton, J.H., Park, C. R.: Interaction of insulin and glucagon in the control of liver metabolism. In: D. F. Steiner, N. Freinkel (Eds.): Handbook of Physiology, p. 437. Washington D. C.: American Physiological Society 1972

26. Khoo, J. C., Steinberg, D., 'Thompson, B., Mayer, S. E.: Hormonal regulation of adipocyte enzymes. The effects of epinephrine and insulin on the control of lipase, phosphorylase kinase, phosphorylase, and glycogen synthase. J. Biol. Chem. 248, 3823-3830 (1973)

27. Siddle, K. and Hales, C.N.: The relationship between the concentration of adenosine $3^{\prime}: 5^{\prime}$-cyclic monophosphate and the anti-lipolytic action of insulin in isolated rat fat-cells. Biochem. J. 142, 97-103 (1974)

28. Rasmussen, H., Tenenhouse, A.: Cyclic adenosine monophosphate, $\mathrm{Ca}^{++}$and membranes. Proc. Natl. Acad. Sci. USA 59, 1367-1370 (1968)

29. Illiano, G., Tell, G.P.E., Siegel, M.I., Cuatrecasas, P.: Guanosine $3^{\prime}: 5^{\prime}$-cyclic monophosphate and the action of insulin and acetylcholine. Proc. Natl. Acad. Sci. USA 70, 2443-2447 (1973)

30. Pawlson, I. G., Lovell-Smith, C. J., Manganiello, V.C., Vaughan, M.: Effects of epinephrine, adrenocorticotrophic hormone, and theophylline on adenosine $3^{\prime}, 5^{\prime}$-monophosphate phosphodiesterase activity in fat cells. Proc. Natl. Acad. Sci. USA 71, 1639-1642 (1974)

31. Birnbaumer, L.: Hormone-sensitive adenylyl cyclases. Useful models for studying hormone receptor functions in cell-free systems. Biochim. Biophys. Acta 300, 129-158 (1973)

32. Zinman, B., Hollenberg, C. H.: Effect of insulin and lipolytic agents on rat adipocyte low $\mathrm{K}_{\mathrm{M}}$ cyclic adenosine $3^{\prime}: 5^{\prime}$-monophosphate phosphodiesterase. J. Biol. Chem. 249, 21822187 (1974)

33. Häring, H. U., Renner, R., Hepp, K. D.: Hormonal control of cyclic AMP turnover in isolated fat cells. Mol. Cell. Endocrinol. 5, 295-302 (1976)

34. Hepp, K. D.: Inhibition of glucagon-stimulated adenyl cyclase by insulin. FEBS I ett. 12, 263-266 (1971)

35. Hepp, K.D.: Adenylate cyclase and insulin action. Effect of insulin, nonsuppressible insulin-like material, and diabetes on adenylate-cyclase activity in mouse liver. Eur. J. Biochem. 31, 266-276 (1972)

36. Jefferson, L. S., Hxton, J.H., Butcher, R.W., Sutherland, E.W., Park, C.R.: Role of adenosine $3^{\prime}: 5^{\prime}$-monophosphate in the effects of insulin and anti-insulin serum on liver metabolism. J. Biol. Chem. 243, 1031-1038 (1968)

37. Birnbaumer, L., Pohl, S.L., Rodbell, M.: Adenyl cyclase in fat cells. I. Properties and the effects of adrenocorticotropin and fluoride. J. Biol. Chem. 244, 3468-3476 (1969)

38. Birnbaumer, L., Rodbell, M.: Adenyl cyclase in fat cells. II. Hormone receptors. J. Biol. Chem. 244, 3477-3482 (1969)

39. Hepp, K. D., Renner, R.: Insulin action on the adenylate cyclase system: antagonism to activation by lipolytic hormones. FEBS Lett. 20, 191-194 (1972)

40. Renner, R., Kemmler, W., Hepp, K. D.: Antagonism of insulin and lipolytic hormones in the control of adenylate-cyclase activity in fat cells. Eur. J. Biochem. 49, 129-141 (1974)

41. Kono, T.: Destruction and restoration of the insulin effector system of isolated fat cells. J. Biol. Chem. 244, 5777-5784 (1969)

42. Hepp, K. D., Renner, R., Langley, J., Häring, H. U.: Effect of partially purified NSILA on adenylate cyclase, phosphodiesterase and $3^{\prime}, 5^{\prime}$-cyclic AMP in fat cells. Mol. Cell. Endocrinol. 3, 309-321 (1975)

43. Illiano, G., Cuatrecasas, P.: Modulation of adenylate cyclase activity in liver and fat cell membranes by insulin. Science 175, 906-908 (1972) 
44. De Asua, L.J., Surian, E.S., Flawia, M.M., Torres, H.N.: Effect of insulin on the growth pattern and adenylate cyclase activity of BHK fibroblasts. Proc. Natl. Acad. Sci. USA 70, 1388-1392 (1973)

45. Kuo, W. N., Hodgkins, D. S., Kuo, J. F.: Adenylate cyclase in islets of Langerhans. Isolation of islets and regulation of adenylate cyclase activity by various hormones and agents. J. Biol. Chem. 248, 2705-2711 (1973)

46. Flawia, M.M., Torres, H.N.: Adenylate cyclase activity in neurospora crassa. III. Modulation by glucagon and insulin. J. Biol. Chem. 248, 4517-4520 (1973)

47. Combret, Y., Laudat, P.: Adenyl cyclase activity in a plasma membrane fraction purified from "ghosts" of rat fat cells. FEBS Lett. 21, 45-48 (1972)

48. Schönhöfer, P.S., Skides: measurement by radioimmunoassay of cyclic AMP. Biochim. Biophys. Acta 304, 541-551 (1973)

50. Pilkis, S. J., Exton, J.H., Johnson, R. A., Park, C. R.: Effects of glucagon on cyclic AMP and carbohydrate metabolism in livers from diabetic rats. Biochim. Biophys. Acta 343, 250-267 (1974)

51. Cuatrecasas, P.: Hormone receptors - their function in cell membranes and some problems related to methodology. Adv. Cyclic Nucleotide Res. 5, 79-104 (1975)

52. Loten, E. G., Sneyd, J. G. T.: An effect of insulin on adiposetissue adenosine $3^{\prime}: 5^{\prime}$-cyclic monophosphate phosphodiesterase. Biochem. J. 120, 187-193 (1970)

53. Senft, G., Schultz, G., Munske, K., Hoffmann, M.: Influence of insulin on cyclic $3^{\prime}, 5^{\prime}$-AMP phosphodiesterase activity in liver, skeletal muscle, adipose tissuc, and kidney. Diabetologia 4, 322-329 (1968)

54. Hollenberg, C. H.: Hormonal effects on cyclic nucleotide phosphodiesterase in adipose tissue, V. Int. Congr. Endocrinology, Hamburg, July 18-24, 1976

55. Desai, K.S., Hollenberg, C.H.: Activation of adipocyte low $\mathrm{K}_{\mathrm{M}} 3^{\prime} 5^{\prime}$-cyclic AMP phosphodiesterase by insulin; Role of $\mathrm{Ca}^{++}$(Abs.) Adv. Cyclic Nucleotide Res. 5, 805 (1975)

56. Häring, H. U., Renner, R., Hepp, K. D.: unpublished results

57. Fain, J.N., Butcher, F. R.: Cyclic guanosine $3^{\prime}: 5^{\prime}$-monophosphate and the regulation of lipolysis in rat fat cells. J. Cyclic Nucleotide Res. 2, 71-78 (1976)
58. Clausen, T., Elbrink, J., Martin, B. R.: Insulin controlling calcium distribution in muscle and fat cells. Acta Endocrinol. (Kbh) 77, Suppl. 191, 137-143 (1974)

59. Siddle, K., Hales, C.N.: The action of local anaesthetics on lipolysis and adenosine $3^{\prime}: 5^{\prime}$-cyclic monophosphate content in isolated rat fat cells. Biochem. J. 142, 345-351 (1974)

60. Kissebah, A.H., Vydelingum, N., Tulloch, B.R., Hope-Gill, H., Fraser, T. R.: Role of calcium in insulin action. I. Purification and properties of the enzymes regulating lipolysis in the human adipose tissue: effects of calcium and cyclic-AMP. Horm. Metab. Res. 6, 247-255 (1974)

61. Severson, D.L., Denton, R.M., Bridges, B.J., Randle, P.J.: Exchangeable and total calcium pools in mitochondria of rat epididymal fat-pads and isolated fat-cells. Role in the regulation of pyruvate dehydrogenase activity. Biochem. J. 153, 209-223 (1976)

62. Hope-Gill, H.: Mediation of the effects of adenyl cyclase stimulators and insulin on glycogen synthetase activity through alteration of the intracellular calcium concentration (Abstr.). V. Int. Congr. Endocrinology, Hamburg July 18-24, 1976

63. Kissebah, A.H., Hope-Gill, H., Vydelingum, N., Tulloch, B. R., Clarke, P.V., Fraser, T. R.: Mode of insulin action. Lancet 1975 I, 144-147

64. Hepp, K.D., Langley, J.: Local anaesthetics interfere with catecholamine activation of adenylatc cyclase in fat cells. (In preparation)

Received: January 5, 1977

Dr. K. D. Hepp

Forschergruppe Diabetes und III. Medizinische Klinik

Krankenhaus Schwabing

Kölner Platz 1

D-8000 München 40

Federal Republic of Germany 